\title{
Livskvalitet i ulike deler av Oslo
}

\author{
Victoria Cramer, Svenn Torgersen og Einar Kringlen \\ Diakonhjemmets sykehus FoUavd., Psykologisk institutt, Psykiatrisk institutt, Universitetet i Oslo
}

\begin{abstract}
SUMMARY
This article presents a comprehensive evaluation of different aspects of quality of life in Oslo. A number of sociodemographic variables such as gender, age, income, living alone/together with a partner, population density in the part number of negative life events, is related to quality of life. Surprisingly, education is not that important for quality of life, when income also is considered. Nor is marriage so important. What is important is whether you live together with a partner, married or not. Age seems to be positively related to some aspects of quality of life, negatively related to other aspects. We observed that even if all aforementioned variables were taken into account, the east part of the centre of Oslo had the worst quality of life and the west part of the periphery of Oslo the best quality of life. However, the tendency to a better quality of life in the western periphery was not so pronounced as the tendency to an unfavorable quality of life in the centre east. The centre and peripherial west did not differ much from the average. The western periphery is characterized by harmonious families of origin whereas centre east is characterized by social problems and negative life events.
\end{abstract}

\section{INNLEDNING}

Når mennesket er sikret en alminnelig god levestandard og trusselen om å dø av en rekke uhelbredelige sykdommer avtar, oppstår ønsket om livskvalitet. Det er ikke tilstrekkelig bare å eksistere, hvordan man lever blir også viktig. De fleste vil nok ha en forestilling om hva det gode liv er, men å enes om hvordan livskvalitet skal defineres, er likevel ikke lett (Wilson, 1967; Andrews \& Withey, 1974; Ryff, 1989). Innenfor en medisinsk tradisjon har man nærmest definert livskvalitet som fravær av sykdom, og god effekt av behandling og livslengde blir forstått som god helse og derved livskvalitet (Gurin et al., 1960; Michalos et al., 2000). Dette er vel og bra, men da blir å påvise hvordan det å være syk påvirker livskvaliteten en tautologi. En annen definisjon tar utgangspunkt i sosiodemografiske forhold (Campbell, 1981; Diener, 1994; Diener et al., 1999; Cummins, 1995). Igjen reduserer dette muligheten til å se på sammenhengen mellom sosioøkonomiske forhold og livskvalitet. En tredje tilnærming er å ta utgangspunkt i den subjektive opplevelse. Dermed blir livskvalitet nærmest en personlighetsdimensjon som for eksempel positiv affektivitet (Lykken \& Tellegen, 1996; Diener et al., 1999, Headey et al., 1991; Costa \& McGrae, 1980).

Etter vår oppfatning er det beste utgangspunkt å definere livskvalitet så bredt som mulig og se på en persons sosiale nettverk (House et al., 1988), forhold til egen familie, venner og naboer (Jones, 1991), fravær av ubehagelige opplevelser (Williams et al., 1981), selvrealisering på flere livsområder (Michalos, 1980) og naturlig nok; den subjektive opplevelse av lykke (Sandvik et al., 1993).

Vi har tatt et slikt utgangspunkt i definisjonen av livskvalitet og vil i denne artikkelen se på hvordan livskvalitet er i ulike bydelsregioner i Oslo når man kontrollerer for forskjeller i kjønn, alder, utdannelse, inntekt, ekteskap, samboerskap, og befolkningstetthet i vedkommende bydel. Med andre ord, vi vil undersøke om, i tillegg til relevante sosioøkonomiske og demografiske variabler, det betyr noe hvor man bor i byen, uavhengig av hvor stor befolkningstetthet det er i vedkommende bydel (Mitchell, 1971).

\section{MAteriale}

Materialet er beskrevet $\mathrm{i}$ tidligere artikler (Torgersen et al., 2001; Kringlen et al., 2001). Kort fortalt kan det nevnes at man tok utgangspunkt i 3590 personer mellom 18 og 65 år som var oppført i folkeregisteret som boende i Oslo i 1994. Bare 2693 personer bodde faktisk med sikkerhet i Oslo på kjent adresse. De øvrige hadde enten flyttet ut av byen eller var umulig å finne. 177 var for syke, i fengsel eller på asylmottak eller hadde for store språkproblemer til at de kunne intervjues. Av de gjenværende 2516 personene var det 415 eller $16,5 \%$ som nektet intervju og 35 eller $1,4 \%$ som aldri fant noe tidspunkt for intervju. Til slutt satt vi igjen med 2066 personer som ble intervjuet. Dette var $57,5 \%$ av det opprinnelige materialet.

\section{Metode}

Variabler som alder, sivilstand, samboerskap, utdannelse og inntekt ble fastslått gjennom intervju, likedan livskvalitet som besto av sju aspekter:

Familie: Hvordan var kontakten med familien? De forhåndsangitte fem svarkategoriene gikk fra "dårlig", til "svært god". Skåren ble standardisert slik at gjennomsnittet i populasjonen ble 0 med standardavvik på 1 .

Venner: Var respondenten fornøyd med antallet venner, hvor mye kontakt med vennene hadde man og hvordan var kvaliteten av kontakten. Svarene inngikk i en faktoranalyse, og faktorskåren utgjorde en vennskapsindeks. 
Naboskap: Respondentene ble spurt om hvordan de trives der de bor, om man slår av en prat med naboen når man møtes, om man omgås hverandre, hvor mange som omgår hverandre, om man hjelper hverandre, hvor fornøyd man er med kontakten med naboene, og generelt hvordan forholdet mellom naboene er og om man kan tenke seg å flytte. Svarene inngikk i en faktoranalyse og faktorskårene utgjorde en naboskapsindeks.

Støtte ved sykdom: Respondentene ble spurt om hvorvidt de kunne påregne hjelp og støtte fra familie, venner eller naboer om en ble syk. Svaret på en fem punkt skala fra "svært sannsynlig" til "helt usannsynlig" ble konvertert til standardskåre.

Ubehagelige livshendelser: Respondentene ble spurt om de siste året hadde opplevd ubehagelige livshendelser som brudd i forhold, sykdom, ulykke, overfall, problemer med loven, oppsigelser i arbeidet, økonomiske problemer, vanskeligheter på bostedet (Dalgard et al., 1995). Antall ubehagelige livshendelser ble notert og konvertert til en standardskåre.

Selvrealisering: Det ble spurt om i hvilken grad de følte at de hadde vært $\mathrm{i}$ stand til å tilfredsstille sine behov innen arbeid, nære forhold, vennskap, hobby og lek, seksualitet, sport og helse og innen familien. Svarene som ble skåret fra "veldig bra" til "veldig dårlig" inngikk i en faktoranalyse og faktorskåren utgjorde en selvrealiseringsindeks.

Lykke: Her ble man bedt om å karakterisere sitt liv på en fem punktskala fra "svært lykkelig" til "svært ulykkelig". De ble også bedt om å angi på en titrinnsskala som gikk fra det best tenkelige liv til det verst tenkelige liv, hvor de selv befant seg. Svarene på de to spørsmålene inngikk $\mathrm{i}$ en faktoranalyse og faktorskåren utgjorde en lykkeindeks.

Endelig inngikk alle syv indeksene i en faktoranalyse og faktorskåren utgjorde den samlede, globale livskvalitetsindeks.

\section{Resultater}

Tabell 1 viser interkorrelajonen mellom de ulike delindeksene av livskvalitet. De høyeste korrelasjonene er mellom Forhold til opprinnelsesfamilie og Naboskapsforhold $(0,49)$ og Lykke og Selvrealisering $(0,45)$. De laveste korrelasjonene er mellom Støtte hvis syk og
Naboskapsforhold $(0,14)$, Støtte hvis syk og Forhold til opprinnelsesfamilie $(0,15)$ og Vennekontakt og Fravær av negative livsbegivenheter $(0,15)$.

Tabellen viser at de ulike delindeksene både deler en viss felles varians og danner grupperinger av høyere interkorrelasjoner. Dette er grunnlag for å se nærmere på den underliggende fellesfaktor og delfaktorer.

Tabell 2 viser at Lykke og Selvrealisering er de sterkeste bærere av den underliggende faktor, mens de andre delindeksene viser en jevn, moderat avspeiling av fellesfaktorene.

Varimax rotering viste to klare faktorer med egenverdi over 1,00. Etter disse to var det et knekkpunkt med relativt like lave forklarte varianser.

Tabell 2. Variabelstyrke (communality) og variabel-til-sumkorrelasjonen, fratrukket variabelen, for de ulike delindeksene av livskvalitet.

\begin{tabular}{lcc}
\hline & $\begin{array}{c}\text { Variabelstyrke } \\
\text { (communality) }\end{array}$ & $\begin{array}{c}\text { Variabel-til- } \\
\text { sum-korrelasjon }\end{array}$ \\
\hline Lykke & 0,50 & 0,51 \\
Selvrealisering & 0,43 & 0,45 \\
Vennekontakt & 0,31 & 0,36 \\
Støtte hvis syk & 0,28 & 0,34 \\
Fravær av negative livsbegivenh. & 0,28 & 0,34 \\
Forhold til opprinnelse familie & 0,35 & 0,40 \\
Naboskapsforhold & 0,32 & 0,38 \\
\hline
\end{tabular}

Standardisert Cronbachs alpha 0,69

Tabell 3. Faktorladninger.

\begin{tabular}{lcc}
\hline & $\begin{array}{c}1 . \\
\text { "Generell } \\
\text { subjektiv } \\
\text { tilfredshet" }\end{array}$ & $\begin{array}{c}\text { "Sosial } \\
\text { Integrasjon" }\end{array}$ \\
\hline Lykke & 0,73 & 0,21 \\
Selvrealisering & 0,74 & 0,09 \\
Vennekontakt & 0,61 & 0,10 \\
Støtte hvis syk & 0,62 & 0,05 \\
Fravær av negative livsbegivenheter & 0,38 & 0,34 \\
Forhold til opprinnelse familie & 0,12 & 0,84 \\
Naboskapsforhold & 0,08 & 0,84 \\
Egenverdi & 2,46 & 1,16 \\
\% av varians & 35,1 & 16,5 \\
\hline
\end{tabular}

Tabell 1. Interkorrelasjonene mellom de ulike delindekser av livskvalitet.

\begin{tabular}{lccccccc}
\hline & 1 & 2 & 3 & 4 & 5 & 6 & 7 \\
\hline Lykke & 1,00 & & & & & & \\
Selvrealisering & 0,45 & 1,00 & & & & & \\
Vennekontakt & 0,30 & 0,31 & 1,00 & & & & \\
Støtte hvis syk & 0,28 & 0,30 & 0,23 & 1,00 & & & \\
Fravær av negative livsbegivenheter & 0,33 & 0,17 & 0,15 & 0,18 & 1,00 & & \\
Forhold til opprinnelsesfamilie & 0,25 & 0,19 & 0,16 & 0,15 & 0,23 & 1,00 & \\
Naboskapsforhold & 0,19 & 0,19 & 0,18 & 0,14 & 0,20 & 0,49 & 1,00 \\
\hline
\end{tabular}

Statistisk signifikant $\mathrm{p}<0,001$ for alle korrelasjonene med tohalet test. 
Den første faktoren som vi kalte Generell subjektiv tilfredshet ladet høyt på Lykke, Selvrealisering, Vennekontakt og Støtte hvis syk. Den andre som vi kalte Sosial integrasjon-faktoren ladet høyt på Forhold til opprinnelsesfamilie og Naboskapsforhold. De enkelte delindekser viste ladning på bare en av faktorene, bortsett fra Fravær av negative livsbegivenheter som ladet moderat lavt på begge faktorer.

To-faktor løsningen syntes å gi et klart bilde av strukturen i delindeksene.

Tabell 4 viser vår inndeling $\mathrm{i}$ fem bydelsregioner. De er delt opp slik at det befinner seg like mange, 400500 personer, i hver region, og regionene er sammenhengende. De går fra sentrum til periferi i retning øst, vest og sør. Dermed har det ikke vært særlig rom for skjønn i grensedragningen. Sentrum øst og vest består av tett bebyggelse, periferi øst av nyere og litt eldre blokkbebyggelse og villaer, periferi vest består vesentlig av villaer, sør av noe ny og gammel blokkbebyggelse, men ganske mye villaer. I urbaniseringsgrad er sentrum mest utpreget, fulgt av periferi øst, sør og periferi vest som den mer velstående, rolige forstadsbebyggelse. Sentrum vest er også mer velstående enn sentrum øst.

Tabell 5 viser at den samlede globale livskvalitetsindeks er høyest i gjennomsnitt i Periferi vest og lavest i Sentrum øst. De tre andre bydelsregionene kommer $i$ en mellomstilling, der Sør kommer best ut, etterfulgt av Sentrum vest og Periferi øst.

Faktoren Sosial integrasjon fordeler seg på de ulike bydelsregionene som den samlede livskvalitetsindeksen, bortsett fra at Sentralt Vest kommer relativt dårligere ut. Faktoren Generell subjektiv tilfredshet slår først og fremst ut i lav skåre Sentralt øst.

Ser vi på de enkelte delindekser finner vi at det er i antall negative livsbegivenheter Sentralt øst fremhever seg med lav livskvalitet. Forhold til opprinnelses- familie og naboskapsforhold er særlig bra i Periferi vest. Dette framkom også i den høye skåren på Sosial integrasjon i Periferi vest. Relativt sett er Sentrum vest særlig dårlig på Naboskapsforhold. Sør er særlig bra på Fravær av negative livsbegivenheter. Det er også Periferi øst, relativt sett, men den er relativt dårlig på Lykke, Forhold til opprinnelsesfamilie og Naboskapsforhold.

Tabell 4. Bydelsregioner.

\begin{tabular}{rll}
\hline Nummer & Navn & Region i Oslo \\
\hline 4 & Sagene-Torshov & Sentrum Øst \\
5 & Grünerløkka-Sofienberg & Sentrum Øst \\
6 & Gamle Oslo & Sentrum Øst \\
14 & Helsfyr-Sinsen & Sentrum Øst \\
1 & Bygdøy-Frogner & Sentrum Vest \\
2 & Uranienborg-Majorstua & Sentrum Vest \\
3 & St.Hanshaugen-Ullevål & Sentrum Vest \\
7 & Ekeberg-Bekkelaget & Sør \\
8 & Nordstrand & Sør \\
9 & Søndre Nordstrand & Sør \\
10 & Lambertseter & Sør \\
11 & Bøler & Sør \\
12 & Manglerud & Sør \\
13 & Østensjø & Sør \\
15 & Hellerud & Periferi Øst \\
16 & Furuset & Periferi Øst \\
17 & Stovner & Periferi Øst \\
18 & Romsås & Periferi Øst \\
19 & Grorud & Periferi Øst \\
20 & Bjerke & Periferi Øst \\
21 & Grefsen-Kjelsås & Periferi Vest \\
22 & Sogn & Periferi Vest \\
23 & Vinderen & Periferi Vest \\
24 & Røa & Periferi Vest \\
25 & Ullern & Periferi Vest \\
\hline & &
\end{tabular}

Tabell 5. Gjennomsnitt og standardavvik (SD) for de ulike delindeksene, de to faktorene og samlet livskvalitetsindeks.

\begin{tabular}{|c|c|c|c|c|c|c|c|c|c|c|c|}
\hline & \multirow[b]{2}{*}{$\mathrm{F}$} & \multicolumn{2}{|c|}{ Sentralt Øst } & \multicolumn{2}{|c|}{ Sentralt Vest } & \multicolumn{2}{|l|}{ Sør } & \multicolumn{2}{|c|}{ Periferi Øst } & \multicolumn{2}{|c|}{ Periferi Vest } \\
\hline & & Gj.sn. & $\mathrm{SD}$ & Gj.sn. & $\mathrm{SD}$ & Gj.sn. & SD & Gj.sn. & $\mathrm{SD}$ & Gj.sn. & $\mathrm{SD}$ \\
\hline Lykke & $7,79^{\mathrm{A}}$ & $-0,19^{3,5}$ & 1,08 & $-0,05$ & 1,08 & $0,09^{1}$ & 0,91 & $-0,08^{5}$ & 1,02 & $0,16^{1,4}$ & 0,93 \\
\hline Selvrealisering & $6,05^{\mathrm{A}}$ & $-0,22^{2,3,5}$ & 1,20 & $0,03^{1}$ & 1,02 & $0,05^{1}$ & 0,86 & $-0,03$ & 0,97 & $0,11^{1}$ & 0,97 \\
\hline Kontakt venner & 2,36 & $-0,13$ & 1,12 & $-0,02$ & 0,99 & 0,05 & 0,97 & $-0,01$ & 1,03 & 0,06 & 0,90 \\
\hline Støtte hvis syk & 1,82 & $-0,08$ & 1,23 & 0,01 & 1,00 & 0,02 & 0,92 & $-0,06$ & 1,06 & 0,09 & 0,82 \\
\hline Fravær av neg. livshend. & $21,69^{\mathrm{A}}$ & $-0,42^{2,3,4,5}$ & 1,35 & $-0,02^{1}$ & 0,89 & $0,14^{1}$ & 0,82 & $0,02^{1}$ & 1,06 & $0,17^{1}$ & 0,77 \\
\hline Forhold til oppr. familie & $17,68^{\mathrm{A}}$ & $-0,28^{3,5}$ & 1,18 & $-0,07^{5}$ & 1,09 & $0,05^{1,5}$ & 0,89 & $-0,09^{5}$ & 0,95 & $0,28^{1,2,3,4}$ & 0,88 \\
\hline Naboskapsforhold & $14,09^{\mathrm{A}}$ & $-0,21^{3,5}$ & 1,13 & $-0,17^{3,5}$ & 1,02 & $0,08^{1,2}$ & 0,86 & $-0,07^{5}$ & 0,97 & $0,24^{1,2,4}$ & 1,00 \\
\hline Generell subj. tilfredshet & $6,68^{\mathrm{A}}$ & $-0,22^{3,5}$ & 1,18 & $0,03^{1}$ & 1,01 & $0,08^{1}$ & 0,87 & $-0,04$ & 1,04 & $0,12^{8}$ & 0,90 \\
\hline Sosial integrasjon & $22,08^{\mathrm{A}}$ & $-0,30^{3,4,5}$ & 1,18 & $-0,13^{3,5}$ & 1,04 & $0,09^{1,5}$ & 0,84 & $-0,08^{1,5}$ & 0,97 & $0,30^{1,2,3,4}$ & 0,91 \\
\hline Samlet livskvalitet & $21,75^{\mathrm{A}}$ & $-0,36^{2,3,4,5}$ & 1,19 & $-0,05^{1}$ & 1,00 & $0,11^{1,4}$ & 0,87 & $-0,08^{1,3,5}$ & 1,00 & $0,27^{1,2,4}$ & 0,87 \\
\hline
\end{tabular}

A: F-ratio, sign. $\mathrm{p}<0,0001$

1: Signifikant forskjellig fra sentralt øst, Bonferroni korreksjon

2: Signifikant forskjellig fra sentralt vest, Bonferroni korreksjon

3: Signifikant forskjellig fra sør, Bonferroni korreksjon

4: Signifikant forskjellig fra periferi øst, Bonferroni korreksjon

5: Signifikant forskjellig fra periferi vest, Bonferroni korreksjon 
Kontakt med venner og Støtte hvis syk skiller ikke statistisk signifikant mellom bydelsregionene. Alt i alt var forskjellen på Samlet livskvalitet og Sosial integrasjon mellom Sentrum øst og Periferi vest godt over et halvt standardavvik.

Det er velkjent at det foreligger store sosioøkonomiske og demografiske forskjeller mellom ulike deler av Oslo. Helsetilstanden varierer også (Rognerud og Stensvold, 1997). Vi fant bekreftelse på dette i vår undersøkelse, selv om forskjellene ikke var så store.

Det er også slik at en rekke sosiodemografiske variabler korrelerer med livskvalitet som tabell 6 og 7 viser. Dessuten korrelerer disse variabler innbyrdes. Følgelig har vi lagt inn disse variablene i en multippel regresjonsanalyse sammen med bydelsregionene med livskvalitet som avhengig variabel. Ettersom vi ønsker å forklare forskjellen mellom bydelsregioner, er også befolkningstettheten (antall personer bosatt $\mathrm{i}$ den av de 25 bydelene hvor de lever, delt på flateinnhold av bydelen) inkludert, som også tabell 6 og 7 viser.

Dette er en eksplorerende undersøkelse. Følgelig har vi benyttet Enter, og vi refererer beta-vektene og ikke hvor stort tillegg i forklart varians bydelsregionene utgjør. Vi er også interessert $i$ effekten av de sosiodemografiske variabler i seg selv, ikke bare som kontroller i forbindelse med å påvise en eventuell effekt av bosted.

Tabell 8 viser resultatet. Fordi de fem bydelsregionene til sammen omfatter alle personer, blir en bydelsregion statistisk overflødig. Dataanalysen har kastet ut Sør, som den finner mest gjennomsnittlig og følgelig minst informativ. Tabellen viser at kvinner med god inntekt som lever sammen med en partner og har god somatisk helse er mest lykkelig. Yngre mennesker med god utdannelse og inntekt, som bor sammen med en partner og som er friske og ikke bor i Sentralt øst er mest selvrealiserende. Kvinner med god inntekt og helse har best forhold til venner. Yngre mennesker med god inntekt som bor sammen med en partner og har god helse, har mest støtte hvis syk. De har for øvrig neppe mye behov for denne støtten. Eldre kvinner som har god inntekt og som har samboer (ikke gift), god helse og ikke bor i Sentralt øst blir spart for mange negative livshendelser. Eldre kvinner som har god inntekt, som bor med partner, er friske og som ikke bor i Sentralt øst og særlig bor i Periferi vest har godt forhold til familien de kommer fra. Eldre kvinner som er gift og i god helse og som ikke bor i Periferi øst har gode naboskapsforhold.

Tabell 7. Bivariate korrelasjoner mellom sosiodemografiske variabler og livskvalitetsfaktorer og samlet livskvalitet.

\begin{tabular}{lccc}
\hline & $\begin{array}{c}\text { Generell } \\
\text { subjektiv } \\
\text { tilfredshet }\end{array}$ & $\begin{array}{c}\text { Sosial } \\
\text { integrasjon }\end{array}$ & $\begin{array}{c}\text { Samlet } \\
\text { global } \\
\text { livskvalitet }\end{array}$ \\
\hline Kvinne & $-0,01$ & $0,06^{2}$ & 0,03 \\
Alder & $-0,08^{2}$ & $0,23^{3}$ & $0,08^{2}$ \\
Utdannelse & $0,14^{3}$ & 0,03 & $0,13^{3}$ \\
Inntekt & $0,16^{3}$ & $0,09^{3}$ & $0,18^{3}$ \\
Gift & 0,03 & $0,21^{3}$ & $0,15^{3}$ \\
Bor med partner & $0,22^{3}$ & $0,16^{3}$ & $0,28^{3}$ \\
Somatisk helse & $0,28^{3}$ & $0,08^{3}$ & $0,27^{3}$ \\
Tetthet & $-0,08^{3}$ & $-0,16^{3}$ & $-0,17^{3}$ \\
\hline Sentralt øst & $-0,10^{3}$ & $-0,14^{3}$ & $-0,16^{3}$ \\
Sentralt vest & 0,01 & $-0,05^{1}$ & $-0,02$ \\
Sør & 0,04 & $0,05^{1}$ & $0,07^{2}$ \\
Periferi øst & $-0,02$ & $-0,04$ & $-0,04^{1}$ \\
Periferi vest & $0,06^{2}$ & $0,16^{3}$ & $0,14^{3}$ \\
\hline
\end{tabular}

1: $\mathrm{p}<0,05$ (t-test)

$2: \mathrm{p}<0,01$ (t-test)

3: $\mathrm{p}<0,001$ (t-test)

Tabell 6. Bivariate korrelasjoner mellom sosiodemografiske variabler og livskvalitetsindekser.

\begin{tabular}{lccccccc}
\hline & Lykke & $\begin{array}{c}\text { Selvreali- } \\
\text { sering }\end{array}$ & $\begin{array}{c}\text { Kontakt } \\
\text { venner }\end{array}$ & Støtte syk & $\begin{array}{c}\text { Ikke neg. } \\
\text { livshend. }\end{array}$ & $\begin{array}{c}\text { Familie- } \\
\text { forhold }\end{array}$ & Naboskap \\
\hline Kvinner & 0,01 & $-0,04$ & $0,08^{3}$ & $-0,02$ & 0,01 & $0,06^{2}$ & 0,04 \\
Alder & 0,04 & $-0,05^{1}$ & $-0,01$ & $-0,11^{3}$ & $0,11^{3}$ & $0,14^{3}$ & $0,20^{3}$ \\
Utdannelse & $0,10^{3}$ & $0,17^{3}$ & $-0,01$ & $0,09^{3}$ & $0,09^{3}$ & $0,05^{1}$ & 0,02 \\
Inntekt & $0,14^{3}$ & $0,18^{3}$ & 0,03 & $0,09^{3}$ & $0,12^{3}$ & $0,11^{3}$ & $0,06^{2}$ \\
Gift & $0,12^{3}$ & $0,05^{1}$ & $-0,02$ & 0,02 & $0,10^{3}$ & $0,15^{3}$ & $0,18^{3}$ \\
Bor med partner & $0,28^{3}$ & $0,18^{3}$ & 0,00 & 0,15 & $0,22^{3}$ & $0,15^{3}$ & $0,14^{3}$ \\
Somatisk helse & $0,25^{3}$ & $0,22^{3}$ & $0,13^{3}$ & $0,16^{3}$ & $0,16^{3}$ & $0,12^{3}$ & $0,07^{2}$ \\
Tetthet & $-0,09^{3}$ & $-0,06^{2}$ & $-0,07^{2}$ & $-0,04$ & $-0,17^{3}$ & $-0,13^{3}$ & $-0,13^{3}$ \\
\hline Sentralt Øst & $-0,08^{3}$ & $-0,10^{3}$ & $-0,06^{2}$ & $-0,04$ & $-0,19^{3}$ & $-0,12^{3}$ & $-0,10^{3}$ \\
Sentralt Vest & $-0,02$ & 0,01 & $-0,01$ & 0,01 & $-0,01$ & $-0,03$ & $-0,07^{2}$ \\
Sør & $0,05^{1}$ & 0,03 & 0,03 & 0,01 & $0,08^{3}$ & $-0,03$ & $0,05^{1}$ \\
Periferi Øst & $-0,04^{1}$ & $-0,01$ & 0,00 & $-0,03$ & 0,01 & $-0,05^{1}$ & $-0,03$ \\
Periferi Vest & $0,08^{3}$ & $0,06^{2}$ & 0,03 & $0,05^{1}$ & $0,09^{3}$ & $0,15^{3}$ & 0,13 \\
\hline
\end{tabular}

$1: \mathrm{p}<0,05$ (t-test)

2: $\mathrm{p}<0,01$ (t-test)

3: $\mathrm{p}<0,001$ (t-test) 
Tabell 9 viser resultatene når de ulike livskvalitetsindeksene er fortettet $\mathrm{i}$ to faktorer og $\mathrm{i}$ en global sum indeks. Yngre kvinner med god inntekt og med samlivspartner (gift eller ikke gift), som er friske og som ikke bor i Sentrum øst har høy Generell subjektiv tilfredshet. Eldre kvinner som bor sammen med partner (gift eller ikke gift) med god somatisk helse og som ikke bor i Sentrale eller Perifere øst, men derimot Periferi vest, har god Sosial integrasjon. Samlet global livskvalitet er på topp hos kvinner med god inntekt, som bor sammen med partner, er friske og som ikke bor Sentralt eller Perifert øst i Oslo.

Vi finner altså at somatisk helse og det å bo sammen med en partner i særklasse er de beste prediktorer av livskvalitet. Det å være gift tenderer til å slå negativt ut. Dette skyldes at regresjonsanalysen kombinerer variabler. Fordi det å være gift, uten å bo sammen med en partner er knyttet til dårlig livskvalitet (se negative livshendelser), blir det motsatte positivt, ikke minst ettersom samboere har bra livskvalitet. Samboere tenderer faktisk til å ha bedre livskvalitet enn gifte.

Inntekt er en viktig prediktor av livskvalitet. Den bivariate analysen viste at også utdannelse var relatert til livskvalitet. Men sammenhengen forsvinner nesten helt når inntekt også er med i en regresjonsanalyse. Årsaken er at utdannelse bare bedrer livskvaliteten i den grad den fører til høyere lønn. Med andre ord, inntekt er en moderator mellom utdannelse og livskvalitet.

Det å være kvinne er klart knyttet til høy livskvalitet under hensynstagen til alle andre variabler. Gjør man ikke det blir det å være kvinne av liten betydning.
Grunnen er at de gjerne har lavere inntekt, og de er mer somatisk syke. I den forstand viser variablen kjønn den motsatte utvikling av utdannelse når vi går fra bivariat til multivariat analyse.

Tabell 9. Multippel regresjon med livskvalitetsfaktorer og samlet livskvalitet som avhengige variabler og en rekke sosiodemografiske, somatisk helse og bydelsregioner som uavhengige variabler.

\begin{tabular}{lccc}
\hline & \multicolumn{3}{c}{ Standardisert beta } \\
\cline { 2 - 4 } & $\begin{array}{c}\text { Generell } \\
\text { subjektiv } \\
\text { tilfredshet }\end{array}$ & $\begin{array}{c}\text { Sosial } \\
\text { integrasjon }\end{array}$ & $\begin{array}{c}\text { Samlet global } \\
\text { livskvalitet }\end{array}$ \\
\hline Kvinne & $0,06^{2}$ & $0,08^{3}$ & $0,09^{4}$ \\
Alder & $-0,11^{4}$ & $0,18^{4}$ & 0,02 \\
Utdannelse & 0,04 & 0,01 & 0,04 \\
Inntekt & $0,12^{4}$ & 0,03 & $0,12^{4}$ \\
Gift & $-0,03$ & 0,05 & 0,00 \\
Bor med partner & $0,23^{4}$ & $0,07^{2}$ & $0,22^{4}$ \\
Somatisk helse & $0,24^{4}$ & $0,10^{4}$ & $0,25^{4}$ \\
Tetthet & $-0,01$ & $-0,05$ & $-0,04$ \\
\hline Sentralt øst & $-0,08^{1}$ & $-0,08^{1}$ & $-0,11^{3}$ \\
Sentralt vest & $-0,02$ & $-0,04$ & $-0,04$ \\
Sør & - & - & - \\
Periferi øst & $-0,01$ & $-0,06^{1}$ & $-0,05^{1}$ \\
Periferi vest & $-0,02$ & $0,06^{1}$ & 0,02 \\
\hline Multippel R & $0,39^{\mathrm{A}}$ & $0,33^{\mathrm{A}}$ & $0,44^{\mathrm{A}}$ \\
\hline
\end{tabular}

$1: \mathrm{p}<0,05$ (t-test)

2: $\mathrm{p}<0,01$ (t-test)

3: $\mathrm{p}<0,001$ (t-test)

4: $\mathrm{p}<0,0001$ (t-test)

A: $\mathrm{p}<0,0001$ (F-test)

Tabell 8. Multippel regresjon med livskvalitets delindekser som avhengige variabler og en rekke sosiodemografiske variabler og somatisk helse sammen med byregion som uavhengige variabler.

\begin{tabular}{lccccccc}
\hline & Lykke & $\begin{array}{c}\text { Selvreali- } \\
\text { sering }\end{array}$ & $\begin{array}{c}\text { Kontakt } \\
\text { venner }\end{array}$ & Støtte syk & $\begin{array}{c}\text { Ikke neg. } \\
\text { livshend. }\end{array}$ & $\begin{array}{c}\text { Familie- } \\
\text { forhold }\end{array}$ & Naboskap \\
\hline Kvinner & $0,06^{2}$ & 0,02 & $0,10^{4}$ & 0,01 & $0,06^{1}$ & $0,09^{4}$ & $0,06^{1}$ \\
Alder & $-0,02$ & $-0,09^{3}$ & 0,02 & $-0,17^{4}$ & $0,10^{3}$ & $0,10^{3}$ & $0,14^{4}$ \\
Utdannelse & 0,02 & $0,08^{3}$ & $-0,03$ & 0,02 & 0,04 & 0,00 & 0,01 \\
Inntekt & $0,08^{3}$ & $0,13^{4}$ & $0,05^{1}$ & $0,06^{2}$ & $0,07^{2}$ & $0,07^{2}$ & 0,00 \\
Gift & 0,00 & 0,00 & $-0,05$ & 0,03 & $-0,08^{2}$ & 0,03 & $0,08^{2}$ \\
Bor med partner & $0,26^{4}$ & $0,16^{4}$ & 0,00 & $0,16^{4}$ & $0,18^{4}$ & $0,08^{3}$ & 0,04 \\
Somatisk helse & $0,23^{4}$ & $0,19^{4}$ & $0,14^{4}$ & $0,12^{4}$ & $0,15^{4}$ & $0,13^{4}$ & $0,08^{3}$ \\
Tetthet & $-0,06$ & 0,04 & $-0,05$ & $-0,03$ & $-0,04$ & $-0,03$ & $-0,05$ \\
\hline Sentralt Øst & $-0,06$ & $-0,11^{2}$ & $-0,05$ & 0,00 & $-0,16^{4}$ & $-0,08^{1}$ & $-0,05$ \\
Sentralt Vest & $-0,03$ & $-0,04$ & $-0,01$ & 0,01 & $-0,04$ & $-0,02$ & $-0,05$ \\
Sør & - & - & - & - & - & - & - \\
Periferi Øst & $-0,04$ & 0,00 & $-0,02$ & $-0,01$ & $-0,02$ & $-0,04$ & $-0,06^{1}$ \\
Periferi Vest & $-0,01$ & $-0,02$ & $-0,01$ & 0,01 & $-0,02$ & $0,07^{2}$ & 0,04 \\
\hline Multippel R & $0,39^{\mathrm{A}}$ & $0,34^{\mathrm{A}}$ & $0,19^{\mathrm{A}}$ & $0,27^{\mathrm{A}}$ & $0,34^{\mathrm{A}}$ & $0,29^{\mathrm{A}}$ & $0,28^{\mathrm{A}}$ \\
\hline
\end{tabular}

$1: \mathrm{p}<0,05$ (t-test)

2: $\mathrm{p}<0,01$ (t-test)

3: $\mathrm{p}<0,001(\mathrm{t}$-test)

4: $\mathrm{p}<0,0001$ (t-test)

A: $p<0,0001$ (F-test) 
Høyere alder viser den interessante sammenheng med livskvalitet at den fremmer livskvaliteten på visse områder og hemmer den på andre. Eldre har færre negative livsbegivenheter og bedre forhold til sin nære familie og naboer. På den annen side opplever de mindre selvrealisering og mindre støtte om de er syke. Når det gjelder det siste er det vel av betydning at de også har større behov for støtte enn yngre.

For vårt hovedspørsmål om det å leve $\mathrm{i}$ en bestemt bydelsregion er knyttet til livskvalitet, finner vi at østkanten og særlig Sentralt øst er et område med dårligere livskvalitet, kontrollert for alle mulige kovariater. Periferi vest framkommer ikke som like klart positivt, ettersom forskjellen mellom Sentralt vest, Sør og Periferi vest viskes mer ut når de mange sosiodemografiske variabler legges inn.

Variabelen befolkningstetthet er bivariat negativt relatert til livskvalitet. Men når den opptrer sammen med bydelsregionene mister den statistisk signifikans selv om tendensen fremdeles er til stede. Dette betyr at bydelsregion er viktigere enn selve befolkningstettheten når det gjelder livskvalitet. Man kan si at variabelen Sentralt øst overskygger variabelen befolkningstetthet. Litt på spissen kan man si at problemet med Sentralt øst ikke er den store befolkningstettheten, mens problemet med stor befolkningstetthet er at den særlig gjør seg gjeldende på Sentralt øst. Imidlertid, ettersom både befolkningstetthet og Sentralt vest nærmer seg å være statistisk signifikant negativt relatert til livskvalitet, er en riktigere fortolkning at så vel befolkningstetthet som bosted sentrum er av betydning. Variablene svekker imidlertid hverandre såpass mye i en multippel regresjonsanalyse, at de mister statistisk signifikans.

\section{DISKUSJON}

Våre resultater tyder på at det er mulig å lage en livskvalitetsindeks som dekker et bredt spektrum av ulike livsområder, men som samtidig har noe felles og som kan deles i to hovedområder, global subjektiv tilfredshet og sosial integrasjon.

Hver delindeks viste seg å ha et spesifikt mønster av sosiodemografiske determinanter, selv om variabler som samliv med partner og god helse slo ut på samtlige. Høy inntekt og det å være kvinne var også viktige variabler, mens alder slo ut ulikt alt etter delindeks.

Dette er delvis i samsvar med tidligere undersøkelser som har vist at god helse er viktig for livskvaliteten (Michalos et al., 2000; Gurin et al., 1960; Cummins, 1995; Palmore \& Luikart, 1972; House et al., 1988). Det samme gjelder inntekt (Diener et al., 1999; Diener \& Diener, 1996; Palmore \& Lukart, 1972; Ryff, 1989)
Våre funn bekrefter således at det er bedre å være frisk og rik enn syk og fattig. Det er påfallende at utdannelse i seg selv ikke bedrer livskvaliteten. Dette har også andre undersøkelser funnet (Palmore, 1979; Palmore \& Luikart 1972).

Vi finner som andre, at de som er gift har bedre livskvalitet (Mastekaasa, 1992; Michalos, 1980). Men tar vi hensyn til det å bo sammen med en partner eller ikke, er det denne siste variabelen som slår ut på livskvalitet. Dette betyr at det hjelper ikke på livskvaliteten å være gift hvis man ikke bor sammen med ektefellen, tvert imot. På den annen side, de som bor sammen med en partner uten å være gift, har i gjennomsnitt en utmerket livskvalitet. Således vil variabelen bo sammen/ikke bo sammen stjele all effekten fra det å være gift. Ettersom samboerskap blir stadig mer vanlig over hele Europa, og etter hvert kanskje også USA, er det viktig å ta hensyn til denne variabelen i epidemiologiske undersøkelser.

Når det gjelder hovedproblemstillingen, hvorvidt det har noen effekt å bo i en bestemt bydelsregion $\mathrm{i}$ Oslo, kontrollert for de sosiodemografiske variablene, kroppslig helse og befolkningstetthet $\mathrm{i}$ bydelen hvor en bor, finner vi at livskvaliteten er dårligst i øst, særlig i sentrum. Den er best i periferi vest. Men forskjellen i livskvalitet er ikke særlig stor mellom de ulike bydelsregionene utenom sentrum øst. Det er denne bydelen som særkjennes ved lav livskvalitet, selv når mange sosiodemografiske variabler, befolkningstetthet og kroppslig helse er tatt hensyn til. Hva som er årsaken til dette er det vanskelig å si. Det kan være at denne bydelsregionen skaper dårligere livskvalitet. Men det kan også være at den trekker til seg personer som har en tilbøyelighet til lavere livskvalitet. Det kan være at begge deler er tilfelle eller at det er ukjente andre faktorer typisk for denne bydelsregionen som forklarer den lave livskvaliteten. Det er påfallende at $\mathrm{i}$ den del av byen hvor de sosiodemografiske variabler som går sammen med lav livskvalitet er mest fremtredende, er også livskvaliteten lavest, selv når man kontrollerer for de samme variabler. Det kan være at det å ha mennesker med dårlig livskvalitet rundt seg bidrar til at livskvaliteten synker, eller at man søker til steder hvor livskvaliteten er dårlig, om man har potensialer i seg til dårlig livskvalitet. Men det kan også være at visse områder i seg selv av fysiske, ekologiske grunner skaper dårlig livskvalitet. Om mennesker som ut fra personlige og sosiodemografiske forhold er utsatt for å få dårlig livskvalitet blir tvunget til disse områder av økonomiske årsaker, vil flyttingen ytterligere senke livskvaliteten og man får en selvforsterkende prosess. Bare longitudinelle prosjekter hvor man studerer folks flyttemønster vil kunne kaste lys over disse alternativene. 


\section{REFERANSER}

Andrews FM, Withey SB (1974). Developing measures of perceived life quality: Results from several national surveys. Soc Indic Res, 1, 1-26.

Campbell A (1981). The sense of well-being in America. New York: McGraw-Hill.

Costa PT, Jr, McGrae RR (1980). Influence of extraversion and neuroticism on subjective well-being. J Pers Soc Psychol, 38, 668-678.

Cummins RD (1995). On the trail of the gold standard for subjective-well-being. Soc Indic Res, 35, 179-200.

Dalgard OS, Bjørk S, Tambs K (1995). Social support, negative life events and mental health. Br J Psychiatry, 166, 29-34.

Diener E (1994). Assessing subjective well-being: progress and opportunities. Soc Indic Res, 31, 103-157.

Diener E, Diener C (1996). Subjective well-being. Psychol Bull, 95, 542-575.

Diener E, Suh ME, Lukas RE, Smith LH (1999). Subjective well-being: Three decades of progress. Psychol Bull, 95, 542-575.

Gurin G, Veroff J, Feld S (1960). Americans view of their mental health. New York: Basic Books.

Headey B, Veenhoven R, Wearing (1991). A top-down versus bottom-up theories of subjective well-being. Soc Indic Res, 24, 81-100.

House JS, Landis KR, Umberson D (1988). Social relationships and health. Science, 241, 540-545.

Jones DC (1991). Friendship satisfaction and gender. An examination of sex differences in contributors to friendship satisfaction. $J$ Soc Pers Relat, 8, 167-185.

Kringlen E, Torgersen S, Cramer V (2001). A Norwegian psychiatric epidemiological study. Am J Psychiatry, 158, 1091-1098.

Lykken D, Tellegen A (1996). Happiness is a stochastic phenomenon. Psychol Sci, 7, 186-189.

Mastekaasa A (1992). Marriage and psychological well-being: Some evidence on selection into marriage. $J$ Marriage Fam, 54, 901-911.

Michalos AC, Zumbo BD, Hubley A (2000). Health and quality of life. Soc Indic Res, 51, 245-286.

Michalos AC (1980). Satisfaction and happiness. Soc Indic Res, 8, 385-422.

Mitchell RE (1971). Some social implications of high density housing. Am Sociol Rev, 36, 18-29.

Palmore E (1979). Predictors of successful aging. Gerontologist, 19, 427-431.

Palmore E, Luikart C (1972). Health and social factors related to life satisfaction. J Health Soc Behav, 13, 68-80.

Ryff DC (1989). Happiness is everything, or is it? Exploration on the meaning of psychological well-being. $J$ Pers Soc Psychol, 57, 1069-1081.

Rognerud M, Stensvold I (1997). Oslohelsa. Utredningen om helse, miljø og sosial ulikhet i bydelene. Oslo: Ullevål Sykehus, Klinikk for forebyggende medisin.

Torgersen S, Kringlen E, Cramer V (2001). The prevalence of personality disorders in a community sample. Arch Gen Psychiatry, 58, 590-596.

Williams AW, Ware JE, Jr, Donald CA (1981). A model of mental health, life events and social supports applicable to general populations. J Health Soc Behav, 22, 324-336.

Wilson W (1967). Correlates and avowed happiness. Psychol Bull, 67, 294-306. 